\title{
自己免疫性膵炎診療ガイドライン 2009
}

\section{厚生労働省難治性膵疾患調查研究班 - 日本膵臟学会}

\section{作成委員会}

委 員 長 : 岡崎和一 (関西医科大学消化器肝藏内科)

編集責任委員：岡崎和一 (関西医科大学消化器肝臓内科), 川 茂幸 (信州大学健康安全センター),

神澤輝実（東京都立駒込病院内科）

委 員: 伊藤鉄英 (九州大学病態制御内科), 乾 和郎 (藤田保健衛生大学 - 坂文種報德會病院消化器 内科)，入江裕之(佐賀大学放射線科), 西野隆義（東京女子医科大学八千代医療センター消 化器科), 能登原憲司 (倉敷中央病院病理検查科), 久保惠嗣 (信州大学医学部内科学第一講 座), 大原弘隆 (名古屋市立大学大学院消化器 - 代謝内科学), 入澤篤志 (福島県立医科大学 内科学第二講座), 藤永康成 (信州大学放射線科), 長谷部修 (長野市民病院内科), 西森 功 (高知大学消化器内科), 田中滋城 (昭和大学消化器内科)

\section{Delphi 法による専門家委員会}

委 員 長: 下瀬川徹 (東北大学大学院医学系研究科消化器病態学教授, 厚生労働省難治性膵疾患に関す る調查研究班, 研究代表者)

専門委員 : 岡崎和一, 川 茂幸, 神澤輝実, 伊藤鉄英, 乾 和郎, 西野隆義, 大原弘隆, 西森 功, 田中滋城

\section{評価委員会}

委 員 長 : 田中雅夫 (日本膵㵴学会理事長, 九州大学大学院医学研究院・臨床・腫瘍外科学教授)

委員 : 白鳥敬子 (日本膵臓学会自己免疫性膵炎診断基準委員会委員長, 東京女子医科大学消化器内 科学教授)

須田耕一 (徳洲会病院病理科, 順天堂大学名誉教授)

西山利正（関西医科大学公衆衛生学講座教授） 


\section{序}

自己免疫性膵炎は，1995 年にわが国から世界に発信された新しい疾患概念である。 日本膵臟学会は, 1995 年の慢性膵炎臨床診断基準で, 膵管狭細型慢性膵炎を自己免疫機序が想定される特殊な膵の慢性炎 症としてすでに取り上げている. 厚生労働省難治性膵疾患調査研究班は, 本疾患の重要性を認識し, 2002 年度から独立課題として扱ってきた．本疾患の研究はわが国の膵臟領域の研究者によって形成されてき たと言っても過言ではない. 2002 年の日本膵臟学会による世界初の自己免疫性膵炎診断基準の提唱, 初 めての全国疫学調查, 血清 IgG4 上昇の発見, 多彩な膵外病变の指摘, IgG4 関連硬化性疾患の提唱, 又 テロイド治療のコンセンサス形成, 2006 年の自己免疫性膵炎臨床診断基準の改訂, そして 2008 年 Asian Diagnostic Criteria の提唱へと展開されてきた. 現在, このような潮流は日本から世界へ発信され続けて いる.

厚生労働省難治性膵疾患に関する調查研究班は, 2008 年に自己免疫性膵炎の診療ガイドラインを作成 することを計画し，岡崎和一教授を委員長とする作成委員会を設置して編纂作業を進めてきた．このた び, 最終案が厚生労働省難治性膵疾患に関する調查研究班と日本膵臟学会の合同で, 「膵臟」の特別号と して出版されることになった，本ガイドラインは，世界に情報を発信してきたわが国を代表する膵臟の 専門家が最新の情報を網羅した自己免疫性膵炎診療の集大成である.

本ガイドラインの発刊にあたっては，日本膵臟学会理事諸氏から多大なご支援をいただいた．また， より多くの方々に本ガイドラインを知っていただくため, 本誌発刊と同時に「膵臟」オンラインジャー ナルでも一般公開されることになっている. 自己免疫性膵炎は, さまざまな膵外病変を合併するため, 消化器病を専門とする医師のみならず, 広い臨床領域の医師が扱う疾患である。一方, 高齢者に多い疾 患であり, 膵・胆道癌との鑑別や安全なステロイド治療の実践, 再燃を考虑した経過観察など, 消化器 病領域の専門的知識・技術・経験が求められる疾患でもある. 本ガイドラインが自己免疫性膵炎の診療 に広く役立ち, 本疾患の理解を深め, 診療に貢献できることを心から願っている.

厚生労働省難治性膵疾患に関する調査研究班 研究代表者 東北大学大学院消化器病態学

下瀬川 徹

日本膵臟学会理事長

九州大学大学院臨床 $\cdot$ 腫瘍外科

田中 雅夫

\section{1. 自己免疫性膵炎診療ガイドライン作成の経緯}

自己免疫性膵炎は 1995 年に Yoshida ら ${ }^{11}$ により提唱されたが, 日本膵臟学会の臨床診断基準 $2002^{22}$ およ び改訂版の診断基準 $2006^{3}$ を経て,わが国から発信された新しい疾患概念として, 今や国際的にも認めら れるようになった，最近の症例増加に伴い，(1)非典型的自己免疫性膵炎の診断と治療方針，(2)癌との鑑 別診断, (3)膵外病変の位置づけ, (4)再燃例の診断と治療, (5)海外との診断基準の相違など, 種々の問題 を認めるようになった．これらに対処するために，日本人のための診療ガイドライン作成の機運が高ま り, 厚生労働省難治性膵疾患調查研究班 (研究代表者：下瀬川徹）でワーキンググループが組織され「自 己免疫性膵炎診療ガイドライン」の試案が作成され4), 日本膵臟学会と合同で公表することとなった. 
表 1 エビデンスレベル

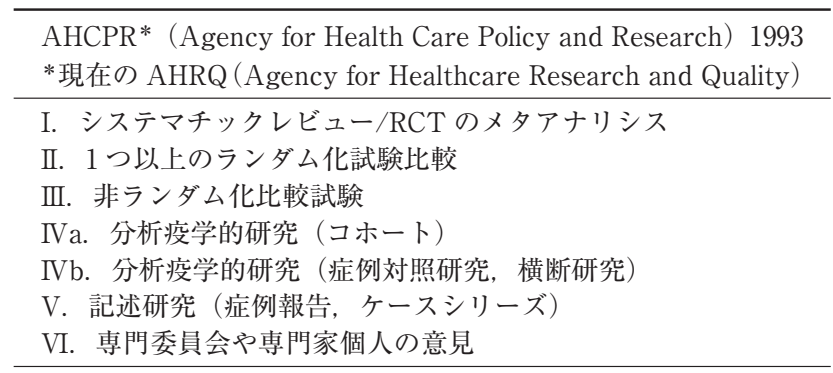

表 2 作成委員会, 専門家委員会, 評価委員会

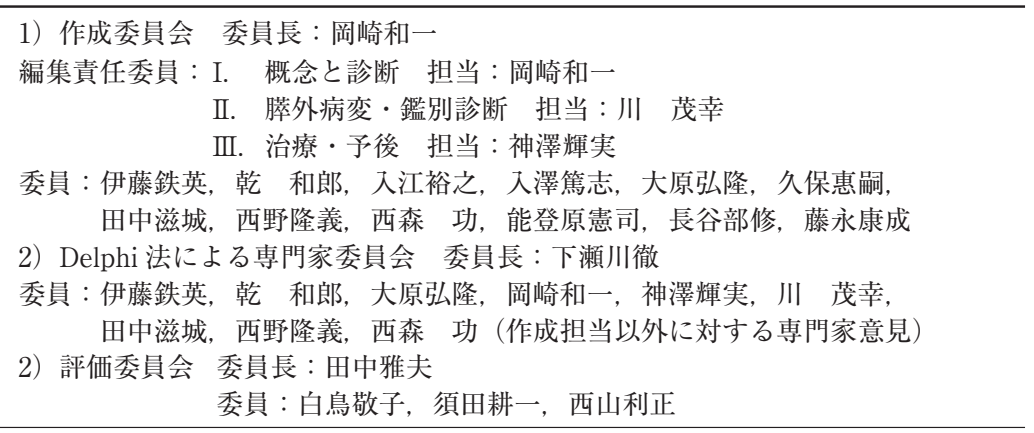

\section{2. 自己免疫性膵炎のエビデンスレベルと Delphi 法に基づくコンセンサスの形成}

厚生労働省難治性膵疾患調査研究班のワーキンググループにより，まずガイドライン作成法が検討さ れた. “autoimmune pancreatitis”, “sclerosing pancreatitis”をキーワードとしたPub Med サーチ（1963 年〜2008 年 4 月）と「自己免疫性脺炎」をキーワードとした中央医学雑誌による関連文献数はそれぞれ 871 編, 1,402 編であった. 財団法人日本医療機能評価機構による Minds 医療情報サービス (http://minds. jcqhc. or. jp/) の推奨する AHCPR (Agency for Health Care Policy and Research) 1993 のエビデンスレ ベル（表 1) に従って，エビデンスの評価を行った。いずれもエビデンスレベル III 以下とエビデンスに そしい文献であり，最終的にコンセンサスに基づくガイドラインを作成することとなった．専門家のコ ンセンサスを得るために, 専門家の意見をより客観的に反映できる Formal Consensus Development (Delphi 法 $)^{5)}$ を採用することとした. 本ガイドライン作成の組織として, 15 人よりなる作成委員会 (膵藏専門 医 11 名, 放射線科医 2 名, 呼吸器内科医 1 名, 病理医 1 名), 専門委員会 (膵臓専門医 10 名), 評価委員 会 (膵臓内科医 1 名, 膵臓外科医 1 名, 病理医 1 名, 公衆衛生専門家 1 名)の 3 委員会が設けられた (表 2)。ただし，自己免疫性膵炎の専門家は少ないため，作成委員が専門家委員を兼ねることになるため， 専門家委員は，お互いに自らの関与しない項目を評価することとした．第一段階として，作成委員会に より, I. 疾患概念と診断 (13 CQs), II. 膵外病変 $(6 \mathrm{CQs})$, III. 鑑別診断 $(6 \mathrm{CQs})$, IV. 治療と予後 (11 CQs) に関して Clinical Questions (CQ) と各ステートメントが作成された. 第二段階として, 各 CQ とステートメントに対して, 専門家委員会が 1 ～点までの 9 段階評価を行った. 第三段階では, 作成委 員会は, 専門家委員会の意見を反映した修正案を作成し, 再度専門家委員会に意見を求めるという作業 を二度繰り返し, 最終的に平均 7 点以上の CQs とステートメントが専門家のコンセンサスの得られたも 
表 3 コンセンサスに基づく推奨度

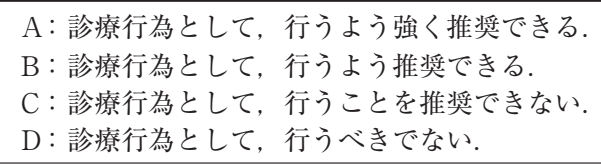

のとされた

\section{3. コンセンサスに基づく推奨度の設定}

本ガイドラインは，上述のようにエビデンスにそしく，エビデンスに基づいた推奨度は設定できない が，専門家のコンセンサスに基づいた推奨度を診断と治療に対して設定した (表 3)。すなわち最終評価 スコアが 9 点のステートメントについて「強く推奨する」（A）または「行うべきでない」(D) に，また 評価スコア 7〜8 点のステートメントについて「推奨できる」(B) または「推奨できない」(C) とした.

\section{文献}

1) Yoshida K, Toki F, Takeuchi T, Watanabe S, Shiratori K, Hayashi N. Chronic pancreatitis caused by an autoimmune abnormality. Proposal of the concept of autoimmune pancreatitis. Dig Dis Sci 1995; 40: 1561-8.

2）日本膵臓学会. 自己免疫性膵炎診断基準 2002 年. 膵臓 $2002 ; 17: 585-7$.

3）厚生労働省難治性膵疾患調查研究班・日本膵臓学会. 自己免疫性膵炎臨床診断基準 2006. 膵臟 $2006 ; 21: 395-7$.

4）岡崎和一，厚生労働省報告書.

5) Fitch K, Bernstein SJ, Aguilar MD, et al. The RAND/UCLA appropriateness method user's manual. Santa Monica CA: RAND, 2001. 


\section{Clinical Questions}

\section{I. 概念と診断}

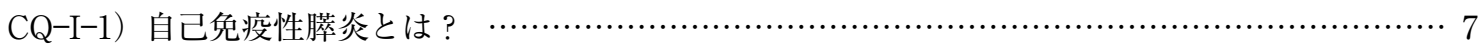

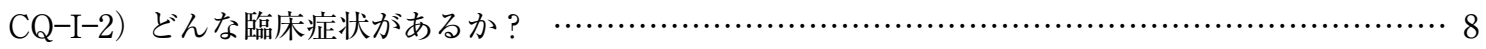

CQ-I-3）発見されるきっかけは何か？ ………………………………………………………..... 8

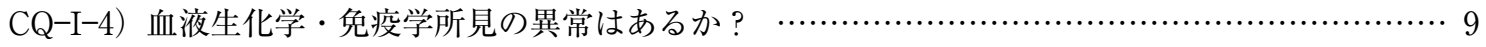

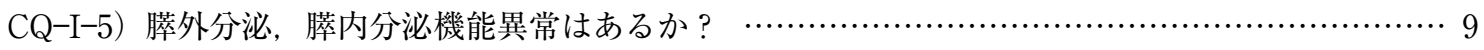

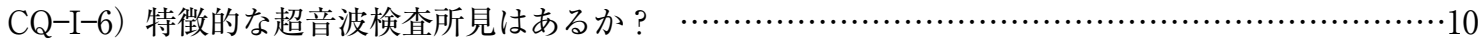

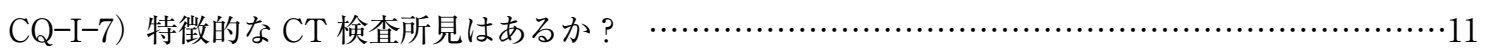

CQ-I-8）特徴的な MRI 検查所見はあるか? MRCP により主膵管の狭細像を評価できるか ? …………12

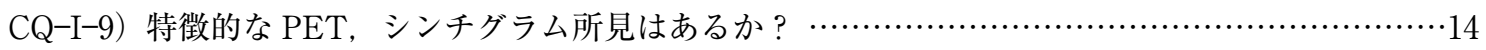

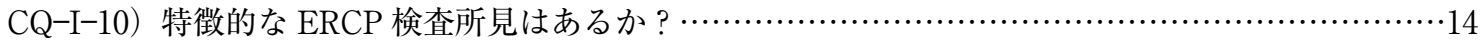

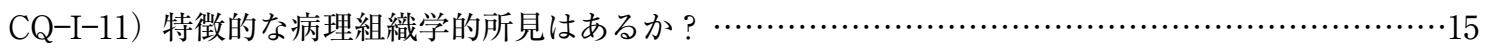

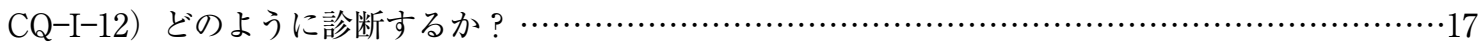

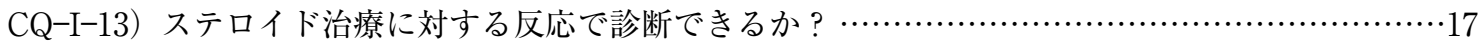

\section{II. 膵外病変}

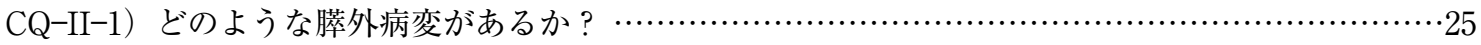

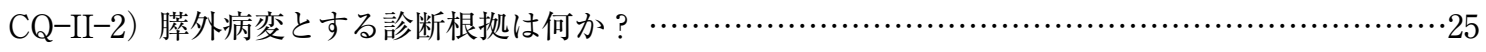

CQ-II-3）合併する涙腺・唾液腺炎と Sjögren 症候群の鑑別点はあるか？…………………….......2 27

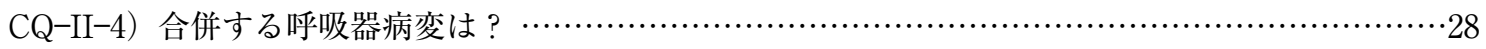

CQ-II-5）合併する硬化性胆管炎と原発性硬化性胆管炎，胆道癌との鑑別点は？………………......22

CQ-II-6）合併する硬化性胆管炎の IDUS 所見は？…………………………………………....

\section{III. 鑑別診断}

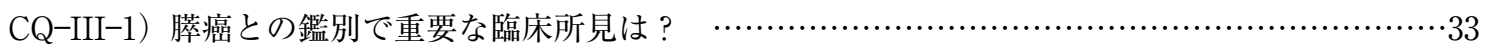

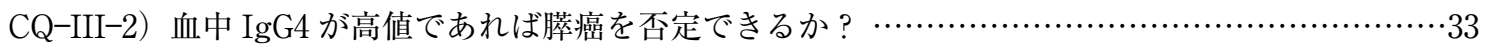

CQ-III-3）自己免疫性膵炎と膟癌との鑑別に有用な CT, MRI 所見は? ………………………….....

CQ-III-4) 自己免疫性膵炎と通常の慢性膵炎，膵癌との鑑別に有用な EUS 所見は？…………….....3

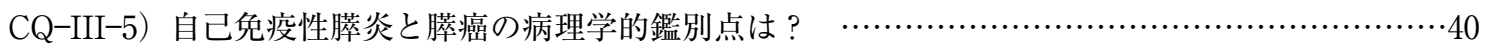

CQ-III-6）自己免疫性膵炎に特徵的な病理所見は膵癌に認められないか？ ……………………....4

IV. 治療, 予後

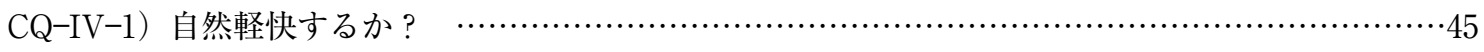

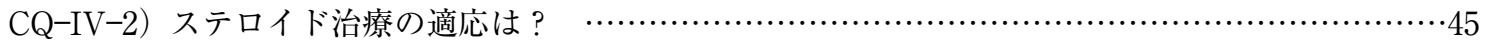

CQ-IV-3） ステロイドの初期治療はどのようにすべきか？

CQ-IV-4）ステロイドの量はどのように減らしていくか？ …….................................................4

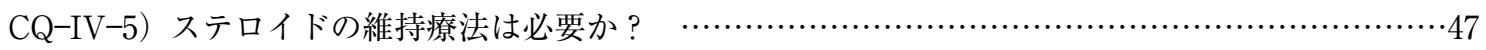

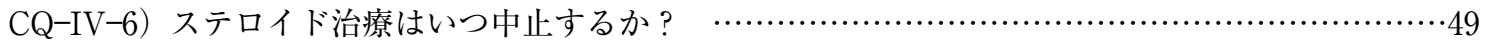

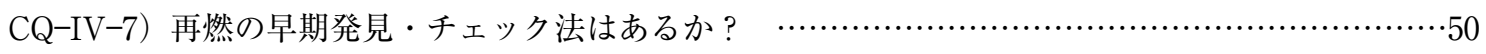

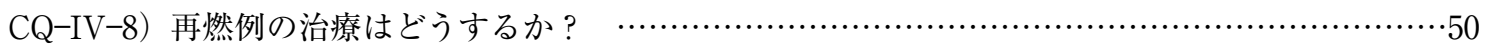




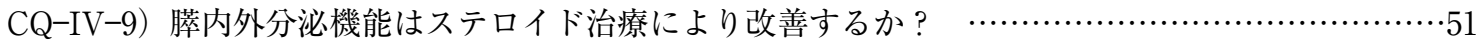

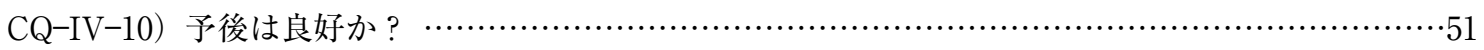

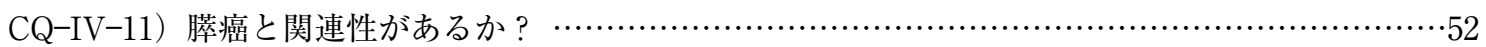

